\title{
WYBRANE DZIAEANIA PROWADZĄCE DO OGRANICZENIA EMISJI SPALIN Z SAMOCHODÓW OSOBOWYCH
}

\section{SELECTED ACTIVITIES LEADING TO MINIMIZE THE CAR'S EXHAUST EMISSIONS}

http://dx.doi.org/10.12775/PPOS.2014.008

\section{STRESZCZENIE}

Celem niniejszego artykułu jest zwrócenie uwagi na kwestię redukcji spalin pochodzących z samochodów osobowych. Przepisy unijne wprowadzają wymogi w zakresie emisji zanieczyszczeń pojazdów silnikowych, które mają przyczynić się do ograniczenia zanieczyszczeń powodowanych przez pojazdy ruchu drogowego. Państwa członkow-

Uniwersytet Gdański, Wydział Prawa i Administracji, Katedra Prawa Gospodarczego Publicznego i Ochrony Środowiska. 
skie Unii Europejskiej, stosując różne metody, starają się zachęcić do używania samochodów bardziej przyjaznych środowisku.

\section{Słowa kluczowe}

Emisja spalin; pojazdy hybrydowe; pojazdy elektryczne; podatki ekologiczne; ochrona powietrza.

\section{ABSTRACT}

The purpose of this article is to draw attention to the issue connected to the reduction of exhaust emissions coming from passenger cars. The EU regulations introduce requirements in the scope of vehicle emissions in order to reduce the pollution caused by vehicle traffic. The European Union Member States use different ways to encourage the use of more environmentally friendly cars.

\section{Keywords}

Exhaust emission; hybrid vehicles; electric vehicles; environmental taxation; air protection.

\section{WPROWADZENIE}

Rozwój branży motoryzacyjnej oprócz faktu, iż przyczynia się do rewolucyjnych zmian w sposobie życia oraz rozwoju gospodarki, oddziałuje również znacząco na środowisko. Zauważyć należy, iż wielkość emisji spalin pochodzących z sektora transportowego wciąż rośnie ${ }^{1}$. Dlatego tak ważny jest aspekt ochrony środowiska oraz ograniczenie negatywnego wpływu

1 Punkt 3 preambuły rozporządzenia nr 443/2009 wskazuje, iż sektor transportu drogowego znajduje się na drugim miejscu wśród sektorów emitujących najwięcej gazów cieplarnianych w Unii. Tak: rozporządzenie Parlamentu Europejskiego i Rady (WE) nr 443/2009 z dnia 23 kwietnia 2009 r. określające normy emisji dla nowych samochodów osobowych w ramach zintegrowanego podejścia Wspólnoty na rzecz zmniejszenia emisji $\mathrm{CO}_{2}$ z lekkich pojazdów dostawczych, Dz.Urz. UE L 140 z 5.06.2009 r., s. 1 ze zm., dalej: rozporządzenie Parlamentu Europejskiego i Rady (WE) nr 443/2009. 
motoryzacji na środowisko. Elementem ochrony środowiska jest ochrona powietrza ${ }^{2}$. Ochrona powietrza ${ }^{3}$ polega na zapewnieniu jak najlepszej jego jakości, poprzez zapobieganie powstawaniu, ograniczanie lub eliminowanie wprowadzanych do powietrza substancji zanieczyszczających w celu zmniejszenia stężeń do dopuszczalnego poziomu lub utrzymanie ich na poziomie nie przekraczającym wielkości dopuszczalnych.

Ochrona powietrza i zapobieganie jego zanieczyszczeniom jest ważnym obszarem ochrony środowiska. Kwestie ochrony powietrza są przedmiotem dyskusji na szczeblu zarówno międzynarodowym, unijnym, jak i krajowym. Walka z zanieczyszczeniem powietrza oraz troska o dobrą jakość powietrza są jednymi z głównych priorytetów Unii Europejskiej. Zagwarantowaniu odpowiedniej jakości powietrza służą unijne przepisy, regulujące między innymi standardy jakości powietrza, emisji zanieczyszczeń. Osiągnięcie europejskiego celu w zakresie jakości powietrza wymaga wysiłków na rzecz redukcji emisji zanieczyszczeń.

Pojęcie zanieczyszczenia powietrza jest bardzo szerokie. W pracy uwaga zostanie skupiona głównie na działaniach mających na celu zapobieganie oraz redukcję emisji $\mathrm{CO}_{2} \mathrm{z}$ samochodów osobowych. Zmniejszenie emisji $\mathrm{CO}_{2} \mathrm{z}$ samochodów osobowych ma nastąpić m.in. dzięki zobowiązaniu przemysłu motoryzacyjnego do zmniejszenia emisji, lepszemu informowaniu konsumentów oraz promowaniu oszczędnych samochodów ${ }^{4}$. W opracowaniu przedstawione zostaną sposoby, które stosują państwa członkowskie Unii Europejskiej w celu redukcji emisji spalin, a tym samym ochrony powietrza. Problematyka ta

2 Art. 3 punkt 39 ustawy z dnia 27 kwietnia 2001 r. Prawo ochrony środowiska, tj. Dz.U. z 2013 r. poz. 1232 ze zm. Jako środowisko rozumie się ogół elementów przyrodniczych, w tym także przekształconych w wyniku działalności człowieka, a w szczególności powierzchnię ziemi, kopaliny, wody, powietrze, krajobraz, klimat oraz pozostałe elementy różnorodności biologicznej, a także wzajemne oddziaływania pomiędzy tymi elementami.

3 Art. 85 ustawy Prawo ochrony środowiska.

4 Na te trzy filary jako filary na których opiera się strategia mająca na celu zmniejszenie emisji $\mathrm{CO}_{2}$ z samochodów wskazuje: punkt 6 preambuły rozporządzenia Parlamentu Europejskiego i Rady (WE) nr 443/2009. 
ma szczególne znaczenie $\mathrm{w}$ aspekcie zapowiadanych przez ministerstwo gospodarki prac nad rozwiązaniami wspierającymi kupno nowszych (bardziej przyjaznych środowisku) aut, a tym samym redukcji emisji spalin.

\section{SPALINY JAKO SUBSTANCJE ZANIECZYSZCZAJĄCE POWIETRZE}

Obecnie występuje wiele definicji pojęcia zanieczyszczenie $^{5}$. Zgodnie z rozporządzeniem (WE) nr 715/2007 Parlamentu Europejskiego i Rady z dnia 20 czerwca 2007 r. w sprawie homologacji typu pojazdów silnikowych w odniesieniu do emisji zanieczyszczeń pochodzących $\mathrm{z}$ lekkich pojazdów pasażerskich i użytkowych (Euro 5 i Euro 6) oraz w sprawie dostępu do informacji dotyczących naprawy i utrzymania pojazdów, pojęcie „zanieczyszczenia gazowe” oznacza emisję tlenku węgla, tlenków azotu, wyrażoną jako odpowiednik dwutlenku azotu $\left(\mathrm{NO}_{2}\right)$ oraz węglowodorów ${ }^{6}$. Rozporządzenie to definiuje również pojęcie emisji spalin z układu wylotowego jako emisję zanieczyszczeń gazowych i cząstek stałych7 ${ }^{7}$ Definicję zanieczyszczenia zawiera również dyrektywa Parlamentu Europejskiego i Rady 2008/50/WE z dnia 21 maja 2008 r. w sprawie jakości powietrza i czystszego powietrza dla Europy. Zgodnie z tymi przepisami zanieczyszczenie to każda substancja znajdująca się w powietrzu, która

5 W tym miejscu uwaga zostanie skupiona tylko na niektórych definicjach pojęcia zanieczyszczenie.

6 Art. 3 pkt 4 rozporządzenia (WE) nr 715/2007 Parlamentu Europejskiego i Rady z dnia 20 czerwca 2007 r. w sprawie homologacji typu pojazdów silnikowych w odniesieniu do emisji zanieczyszczeń pochodzących z lekkich pojazdów pasażerskich i użytkowych (Euro 5 i Euro 6) oraz w sprawie dostępu do informacji dotyczących naprawy i utrzymania pojazdów, Dz.Urz. UE L 171 z 29.06.2007, s. 1. ze zm., dalej jako Rozporządzenie (WE) nr 715/2007.

7 Art. 3 pkt 4 rozporządzenia (WE) nr 715/2007. 
wywołuje prawdopodobieństwo szkodliwego oddziaływania na zdrowie ludzkie i/lub środowisko jako całość ${ }^{8}$.

Zgodnie z przepisami ustawy z dnia 27 kwietnia $2001 \mathrm{r}$. Prawo ochrony środowiska jako zanieczyszczenie rozumiemy emisję, która jest szkodliwa dla zdrowia ludzi lub stanu środowiska, powoduje szkodę w dobrach materialnych, pogarsza walory estetyczne środowiska lub koliduje z innymi, uzasadnionymi sposobami korzystania ze środowiska9. Spaliny jako mieszanina gazów uchodzących z silnika spalinowego, będąca produktem spalania paliw, negatywnie wpływają na środowisko.

W procesie spalania następuje zamiana węglowodorów (paliwa) i powietrza w mieszankę gazów nazywanych spalinami. W skład spalin wchodzą takie substancje jak dwutlenek węgla $\mathrm{CO}_{2}$, tlenek węgla $\mathrm{CO}$, tlenki azotu $\mathrm{NO}_{X}$, węglowodory HC, para wodna $\mathrm{H}_{2} \mathrm{O}$, Azot $\mathrm{N}$, Tlen $\mathrm{O}_{2}$, tlenki siarki $\mathrm{SO}_{\mathrm{x}}$, cząstki stałe. Nie sposób w tym miejscu wskazać dokładnego składu spalin, który zależy zarówno od rodzaju silnika, jak i rodzaju i składu paliwa. Cześć gazów, które wchodzą w skład spalin jest obojętna dla człowieka i środowiska, większa część jednak wywołuje niekorzystny wpływ zarówno na człowieka, jak i na środowisko ${ }^{10}$.

8 Art. 2 pkt 2 dyrektywy Parlamentu Europejskiego i Rady 2008/50/WE z dnia 21 maja 2008 r. w sprawie jakości powietrza i czystszego powietrza dla Europy, Dz.Urz. UE L 152 z 11.06.2008 r., s. 1., dalej: dyrektywa Parlamentu Europejskiego i Rady 2008/50/WE.

9 Art. 3 pkt 49 ustawy Prawo ochrony środowiska.

10 Dwutlenek węgla jest jednym z gazów cieplarnianych i jego ograniczenie ma znaczący wpływ na naszą planetę. Tlenek węgla jest nazywany cichym zabójcą. Jest to bezbarwny, bezwonny i pozbawiony smaku gaz który bardzo łatwo wiąże się z hemoglobiną powodując śmierć. Jest zatem wysoko trujący. Związki azotu czyli tlenki azotu również wiążą się z hemoglobiną, mogą powodować porażenie układu nerwowego oraz choroby układu oddechowego. Oprócz wielu innych związków pojawiają się również cząstki stałe, które są rozpoznawane jako sadza w silnikach wysokoprężnych. 


\section{PODSTAWY PRAWNE W UE}

Aktem prawnym ustanawiającym normy mające na celu regulację emisji $\mathrm{CO}_{2}$ z nowych samochodów osobowych jest rozporządzenie Parlamentu Europejskiego i Rady (WE) nr 443/2009 z dnia 23 kwietnia 2009 r. określające normy emisji dla nowych samochodów osobowych $\mathrm{w}$ ramach zintegrowanego podejścia Wspólnoty na rzecz zmniejszenia emisji $\mathrm{CO}_{2}$ z lekkich pojazdów dostawczych ${ }^{11}$. Ograniczenie określone w rozporządzeniu, dotyczące średniego poziomu emisji $\mathrm{CO}_{2} \mathrm{z}$ nowych samochodów, wynosi $130 \mathrm{~g} \mathrm{CO}_{2}$ na kilometr. Od 2020 r. poziom ten musi być zmniejszony do $95 \mathrm{~g} \mathrm{CO}_{2} / \mathrm{km}$. Przepisy rozporządzenia dotyczą pojazdów kategorii M1, które zostały określone w załączniku II do dyrektywy w sprawie homologacji pojazdów silnikowych $^{12}$ rejestrowanych po raz pierwszy w Unii Europejskiej i które nie były wcześniej zarejestrowane w państwie trzecim. Chodzi w tym przypadku o pojazdy zaprojektowane i wykonane do przewozu osób, mające nie więcej niż osiem siedzeń oprócz siedzenia kierowcy. Rozporządzenie określa nie tylko cele dotyczące średnich emisji $\mathrm{CO}_{2}{ }^{13}$ dla producentów pojazdów, ale również wzory do ich obliczania.

W przypadku przekroczenia docelowych indywidualnych poziomów emisji, producent musi zapłacić dodatkową opłatę. Rozporządzenie wskazuje sposób obliczania opłaty. Wpływy z opłat traktuje się jako dochód budżetu ogólnego. W celu realizacji celów dotyczących emisji indywidualnych, producenci mogą tworzyć grupy producentów. Producenci tworzący grupę przesyłają do Komisji dokumenty zawierające następujące informacje: wykaz producentów, którzy wejdą w skład grupy, nazwę

11 Dz.Urz. UE z. L 140 z 5.06.2009 r., s. 1.

12 Dyrektywa 2007/46/WE Parlamentu Europejskiego i Rady z dnia 5 września 2007 r. ustanawiająca ramy dla homologacji pojazdów silnikowych i ich przyczep oraz układów, części i oddzielnych zespołów technicznych przeznaczonych do tych pojazdów, Dz.Urz. UE L 263 z 9.10.2007 r., s. 1.

13 Rozporządzenie reguluje również kwestię odstępstw od docelowych indywidualnych poziomów emisji - art. 11 rozporządzenia Parlamentu Europejskiego i Rady (WE) nr 443/2009. 
producenta wyznaczonego jako zarządzającego grupą i dowody, że zarządzający grupą będzie w stanie wypełniać swoje obowiązki ${ }^{14}$.

Każde państwo członkowskie zobowiązane jest do gromadzenia informacji dotyczących każdego nowego samochodu osobowego zarejestrowanego na jego terytorium ${ }^{15}$ oraz przekazywania tych danych Komisji. Kwestię monitorowania i sprawozdawczości tych danych szczegółowo reguluje rozporządzenie Komisji (UE) nr 1014/2010 z dnia 10 listopada 2010 r. w sprawie monitorowania i sprawozdawczości danych dotyczących rejestracji nowych samochodów osobowych na mocy rozporządzenia Parlamentu Europejskiego i Rady (WE) nr 443/200916.

Wymogi w zakresie emisji zanieczyszczeń pojazdów silnikowych oraz ich specyficznych części zamiennych na rzecz ograniczenia zanieczyszczeń powodowanych przez pojazdy ruchu drogowego określa Rozporządzenie (WE) nr 715/2007 Parlamentu Europejskiego i Rady z dnia 20 czerwca 2007 r. w sprawie homologacji typu pojazdów silnikowych $\mathrm{w}$ odniesieniu do emisji zanieczyszczeń pochodzących z lekkich pojazdów pasażerskich i użytkowych (Euro 5 i Euro 6) oraz w sprawie dostępu do informacji dotyczących naprawy i utrzymania pojazdów ${ }^{17}$. Rozporządzenie określa również środki, które mają umożliwić poprawę dostępu do informacji dotyczących naprawy pojazdów oraz rozpowszechnienie szybkiej produkcji pojazdów zgodnych z przepisami.

Rozporządzenie ujednolica wymogi techniczne w zakresie homologacji typu pojazdów silnikowych pod kątem emisji zanieczyszczeń. Ma to wyeliminować różnice między wymogami ustanowionymi przez poszczególne państwa członkowskie i zagwarantować wysoki poziom ochrony środowiska naturalne-

14 Kwestię tę reguluje art. 7 rozporządzenia Parlamentu Europejskiego i Rady (WE) nr 443/2009.

15 Zgodnie z art. 8 rozporządzenia Parlamentu Europejskiego i Rady (WE) nr 443/2009.

16 Dz.Urz. UE L 293 z 11.11.2010 r., s. 15.

17 Dz.Urz. UE L 171 z 29.06.2007 r., s. 1. ze zm. 
go. Aby maksymalnie zmniejszyć negatywny wpływ pojazdów drogowych na środowisko oraz zdrowie, rozporządzenie odnosi się do szerokiej gamy substancji zanieczyszczających. Rozporządzenie wskazuje dla każdej kategorii emisji zanieczyszczeń oraz różnych rodzajów pojazdów odpowiednie normy ${ }^{18}$.

Od momentu obowiązywania norm Euro 5 oraz Euro $6^{19}$ państwa członkowskie są zobowiązane odmówić homologacji, rejestracji, sprzedaży oraz wprowadzania do obrotu pojazdów, które nie spełniają podanych wartości dopuszczalnych emisji zanieczyszczeń. Producenci są zobowiązani do wykazania, że wszystkie nowe pojazdy sprzedawane, rejestrowane lub wprowadzane do obrotu posiadają homologację zgodną z wymogami rozporządzenia. Producenci muszą również, oprócz przestrzegania wartości dopuszczalnych emisji, zagwarantować trwałość urządzeń kontrolujących emisję zanieczyszczeń obejmujących przebieg $160000 \mathrm{~km}^{20}$.

Przedstawiając akty prawne mające wpływ na zanieczyszczenie powietrza, należy również poddać krótkiej analizie dyrektywę Parlamentu Europejskiego i Rady 2008/50/WE z dnia 21 maja 2008 r. w sprawie jakości powietrza i czystszego powietrza dla Europy. Dyrektywa ta ustanawia środki, które mają na celu m.in. ocenę jakości powietrza w państwach członkowskich

18 Załącznik I do rozporządzenia wskazuje szczegółowe wartości graniczne emisji Euro 5 i Euro 6. Przykładowo w przypadku normy Euro 5 i emisji pochodzących $\mathrm{z}$ pojazdów wyposażonych w silniki diesel wartości te wynoszą: - tlenek węgla $500 \mathrm{mg} / \mathrm{km}$, - cząstki stałe: $5 \mathrm{mg} / \mathrm{km}$, - tlenki azotu (NOx): $180 \mathrm{mg} / \mathrm{km}$, - łączna masa węglowodorów i tlenków azotu: $230 \mathrm{mg} / \mathrm{km}$. W przypadku normy Euro 5 i emisji pochodzących z pojazdów zasilanych benzyną, gazem ziemnym lub gazem płynnym: - tlenek węgla: $1000 \mathrm{mg} / \mathrm{km}$, - węglowodory niemetanowe: $68 \mathrm{mg} / \mathrm{km}$, - suma węglowodorów: $100 \mathrm{mg} / \mathrm{km}$, - tlenki azotu (NOx): $60 \mathrm{mg} / \mathrm{km}$ - cząstki stałe (jedynie dla pojazdów wyposażonych w silniki z wtryskiem bezpośrednim): $5 \mathrm{mg} / \mathrm{km}$. Inne normy występują dla pojazdów z kategorii N1 i N2. Rozporządzenie określa również wartości graniczne emisji Euro 6.

19 Norma Euro 6 zacznie obowiązywać 1 września 2014 r. w zakresie homologacji, a 1 września 2015 r. w zakresie rejestracji oraz sprzedaży nowych typów pojazdów - art. 10 ust. 4 rozporządzenia (WE) nr 715/2007.

20 Szerzej o obowiązkach producentów art. 4 rozporządzenia (WE) nr 715/2007. 
na podstawie wspólnych metod i kryteriów, zebranie informacji dotyczących jakości powietrza, m.in. w celu obserwowania długoterminowych tendencji, poprawę jakości powietrza. Zgodnie z przepisami dyrektywy państwa członkowskie wyznaczają właściwe organy i podmioty odpowiedzialne za ocenę jakości powietrza, akceptację systemów pomiarowych, zapewnienie właściwości pomiarów, analizę metod oceny, koordynację na swoim terytorium wspólnotowych programów zapewniania jakości, opracowanych przez Komisję, współpracę z innymi państwami członkowskimi oraz Komisją ${ }^{21}$.

Dyrektywa tworzy system oceny jakości powietrza w odniesieniu do dwutlenku siarki, dwutlenku azotu i tlenków azotu, pyłu zawieszonego $\mathrm{PM}_{10}{ }^{22}$ i $\mathrm{PM}_{2,5}{ }^{23}$, ołowiu, benzenu i tlenku węgla, a także ozonu. Przepisy dyrektywy ustanawiają też m.in. progi dla każdej z substancji zanieczyszczających, kryteria dotyczące stosowanej metody ewaluacji, metody referencyjne pomiarów, wartości dopuszczalne dla ochrony zdrowia ludzkiego i środowiska, progi alarmowe oraz poziomy krytyczne w celu ochrony roślinności oraz wykaz informacji wymaganych w planach działań, których celem jest poprawa jakości powietrza.

Jeżeli w określonej strefie lub aglomeracji poziomy zawartości zanieczyszczeń w powietrzu przekraczają wartości dopuszczalne lub wartości docelowe, powiększone o odpowiednie marginesy tolerancji, państwa członkowskie zapewniają opracowanie planów ochrony powietrza dla przedmiotowych stref i aglomeracji ${ }^{24}$. W sytuacji istnienia zagrożenia, iż poziomy zanieczyszczeń $\mathrm{w}$ powietrzu przekroczą progi alarmowe ${ }^{25}$,

21 Art. 3 dyrektywy Parlamentu Europejskiego i Rady 2008/50/WE.

22 „PM 10 ” oznacza pył przechodzący przez otwór sortujący, zdefiniowany w referencyjnej metodzie poboru próbek i pomiaru $\mathrm{PM}_{10}$, EN 12341, przy 50\% granicy sprawności dla średnicy aerodynamicznej do $10 \mu \mathrm{m}$ - art. 2 pkt 18 dyrektywy Parlamentu Europejskiego i Rady 2008/50/WE.

23 „PM $\mathrm{PM}_{2,5}$ ” oznacza pył przechodzący przez otwór sortujący, zdefiniowany w referencyjnej metodzie poboru próbek i pomiaru $\mathrm{PM}_{2,5}$, EN 14907, przy 50\% granicy sprawności dla średnicy aerodynamicznej do 2,5 $\mu \mathrm{m}-$ art. 2 pkt 19 dyrektywy Parlamentu Europejskiego i Rady 2008/50/WE.

24 Art. 23 dyrektywy Parlamentu Europejskiego i Rady 2008/50/WE.

25 Zgodnie $\mathrm{z}$ definicją wskazaną $\mathrm{w}$ art. 2 punkcie 10 dyrektywy Parlamentu Europejskiego i Rady 2008/50/WE „próg alarmowy” oznacza poziom 
państwa członkowskie opracowują krótkoterminowe plany działań $^{26}$ podejmowanych w celu ograniczenia zagrożenia lub skrócenia czasu występowania przekroczenia ${ }^{27}$. Plany działań mogą m.in. zawieszać działania, które przyczyniają się do powstania zagrożenia przekroczenia progów alarmowych. Mogą obejmować sposób organizacji i ograniczeń lub zakaz ruchu pojazdów i innych urządzeń napędzanych silnikami spalinowymi. Państwa członkowskie po sporządzeniu planów działań krótkoterminowych udostępniają je i informują o ich treści odpowiednie organizacje, m.in. organizacje ochrony środowiska, organizacje konsumenckie oraz organizacje reprezentujące interesy wrażliwych grup ludności, oraz inne właściwe instytucje zajmujące się ochroną zdrowia i odpowiednie federacje przemysłowe ${ }^{28}$.

\section{OGRANICZENIE WJAZDU DO CENTRUM MIASTA JAKO PRZYKŁADOWE ROZWIĄZANIE MAJĄCE OGRANICZYĆ POZIOM ZANIECZYSZCZENIA POWIETRZA}

Miasta europejskie stosują wiele sposobów w celu ograniczenia poziomu zanieczyszczenia powietrza. Część miast szczególnie w regionach silnie zurbanizowanych wprowadziło całkowite lub czasowe zakazy poruszania się pojazdami spalinowymi na ich terenie.

W niektórych miastach europejskich wprowadzone zostały zakazy wjazdu do centrów miast lub zakazy wjazdu samocho-

substancji w powietrzu, powyżej którego istnieje zagrożenie dla zdrowia całej ludności, wynikające z krótkotrwałego narażenia na działanie zanieczyszczeń i w przypadku którego państwa członkowskie podejmują natychmiastowe działania. Progi alarmowe określa Załącznik XII dyrektywy 2008/50/WE.

${ }^{26} \mathrm{~W}$ Polsce kwestię tę reguluje: rozporządzenie Ministra Środowiska z dnia 11 września 2012 r. w sprawie programów ochrony powietrza oraz planów działań krótkoterminowych, Dz.U. z 2012, poz. 1028.

27 Odnośnie planów działań krótkoterminowych: art. 24 dyrektywy 2008/50/WE.

${ }^{28}$ Art. 24 ust. 3 dyrektywy 2008/50/WE. 
dów, które nie spełniają określonych norm emisji spalin. Miastami, do których aby wjechać do centrum należy spełnić określone normy emisji są niektóre miasta niemieckie ${ }^{29}$ jak np. Frankfurt nad Menem czy Kolonia. Samochody poruszające się w tych miastach muszą posiadać specjalną nalepkę określającą normę emisji spalin, która umieszczana jest na przedniej szybie auta. Naklejki te wydawane są na wniosek użytkownika pojazdu w oparciu o dane z dowodu rejestracyjnego pojazdu. Na chwilę obecną tylko auta spełniające normę emisji spalin Euro $4^{30}$ i wyższą mogą poruszać się na terenie tych miast ${ }^{31}$. Brak naklejki skutkuje mandatem karnym. Wyjątek od tej reguły stanowią sytuacje losowe jak dojazd do najbliższej stacji benzynowej czy dojazd do szpitala. Jednak każdy taki przypadek jest rozpatrywany indywidualnie.

Należy zauważyć, iż omawiane miasta maja bardzo mocno rozbudowana infrastrukturę parkingową na obrzeżach miast. Istnieje wiele parkingów samochodowych typu Park\&Ride, które są połączone komunikacją miejską z centrami miast. Parkingi te są ulokowane w okolicach każdej głównej drogi dojazdowej i są dobrze oznakowane i utrzymane. Jest to duża zachęta do przesiadki na komunikację miejską. Należy zauważyć, iż część polskich miast zaczęło wprowadzać tego typu parkingi. Jednak skala tych działań jest zbyt mała, a i samo działanie komunikacji miejskiej nie sprzyja rozwojowi tego typu przedsięwzięć.

29 Augsburg, Berlin, Bochum, Bonn, Bottrop, Bremen, Dortmund, Duisburg, Düsseldorf, Essen, Frankfurt/Main, Freiburg/Breisgau, Gelsenkirchen, Hannover, Heidelberg, Heilbronn, Herrenberg, Ilsfeld, Karlsruhe, Köln, Leipzig, Leonberg, Ludwigsburg, Mannheim, Mühlacker, Müllheim/Ruhr, München, Münster, Neu-Ulm, Oberhausen, Osnabrück, Pleidelsheim, Pfinztal, Pforzheim, Recklinghausen, Reutlingen, Schwäbisch-Gmünd, Stuttgart, Tübingen, Ulm, Wuppertal. Lista aktualnych miast: http://www.umwelt-plakette.de.

30 http://www.umwelt-plakette.de/schluesselnummerntabelle.php.

31 Należy zauważyć, iż część miast niemieckich (szczególnie miasta z landu NRW), które wprowadziły ograniczenie wjazdu do centrum, umożliwiają jednak wjazd samochodom nie tylko z zielonymi nalepkami, ale również z żółtymi. 


\section{OPODATKOWANIE SAMOCHODÓW OD EMISJI SPALIN}

Silniki spalinowe $\mathrm{w}$ trakcie swojej pracy produkują duże ilości spalin. W celu zmuszenia lub nakłaniania właścicieli do wymiany starszych samochodów wydalających większe ilości spalin na nowsze i bardziej ekologiczne niektóre państwa wprowadziły opodatkowanie aut od emisji spalin. Tego typu opodatkowanie stosowane jest w 19 państwach Europy. Tymi państwami są: Austria, Belgia, Cypr, Dania, Finlandia, Francja, Niemcy, Grecja, Irlandia, Łotwa, Luksemburg, Malta, Holandia, Portugalia, Rumunia, Słowenia, Hiszpania, Szwecja, Wielka Brytania. Opodatkowanie przybiera różne formy: od restrykcyjnej - nakładającej uciążliwe obowiązki na właścicieli pojazdów, po środki mające zachęcić do kupna nowego i bardziej przyjaznego ekologicznie auta ${ }^{32}$. Nawet na terenie jednego państwa często podatki ekologiczne ${ }^{33}$ różnią się wysokością w zależności od regionu.

Podejście restrykcyjne jest widoczne w takich krajach jak Niemcy, czy Grecja. W Niemczech roczny podatek ekologiczny wynosi 2 euro za każde 100 centymetrów sześciennych pojemności silnika benzynowego i 9,50 euro za każde 100 centymetrów sześciennych pojemności silnika wysokoprężnego. Dodatkowo silniki emitujące powyżej $95 \mathrm{~g} \mathrm{CO}_{2} / \mathrm{km}$ są obłożone podatkiem liniowym w wysokości 2 euro za każdy gram ${ }^{34}$. W Grecji, od 2001 roku funkcjonuje progresywny podatek ekologiczny wąchający się od 0,90 euro za gram $\mathrm{CO}_{2}$ w przypadku emisji z przedziału 101-120g/100km do 3,4 euro za gram dla silników emitujących ponad $225 \mathrm{~g} \mathrm{CO}_{2} / 100 \mathrm{~km}$. Z powyższej analizy

32 Analiza i przedstawienie rodzajów opodatkowania została dokonana w oparciu o dane zgromadzone i przedstawione przez ACEA (European Automobile Manufacturer's Association) - Europejskie Stowarzyszenie Producentów Pojazdów - http://www.acea.be/uploads/publications/CO2_tax_overview 2013.pdf

${ }^{33}$ Podatki ekologiczne w tym opracowaniu obejmują szeroko pojęte ekonomiczno-prawne instrumenty ochrony środowiska.

34 Od pierwszego lipca 2009 do 31 grudnia 2013 silniki emitujące powyżej $110 \mathrm{~g} / \mathrm{km}$ podlegały opodatkowaniu w wysokości 2 euro za każdy gram. 
można zauważyć, iż na posiadaczy starych aut z silnikiem diesla powszechnie uznawanych za najbardziej trujące są nakładane większe należności niż na właścicieli nowszych samochodów lub właścicieli samochodów zasilanych innym rodzajem paliwa.

W niektórych krajach podatek ekologiczny płacony jest zarówno w chwili rejestracji, jak i jako podatek roczny. I tak np. na Malcie płaci się podatek w chwili rejestracji pojazdu, który jest uzależniony od emisji $\mathrm{CO}_{2}$, długości i wartości samochodu oraz dodatkowo rocznie podatek ekologiczny wyłącznie od emisji $\mathrm{CO}_{2}$, który wynosi od 100 do 180 euro. Podobna sytuacja ma miejsce na terenie Irlandii. W chwili rejestracji pojazdu płacony jest podatek, który jest uzależniony od emisji $\mathrm{CO}_{2}$ i wynosi od $14 \%$ do $36 \%$ wartości auta, a dodatkowo płacony jest roczny podatek wynoszący od 120 euro do 2350 euro $^{35}$.

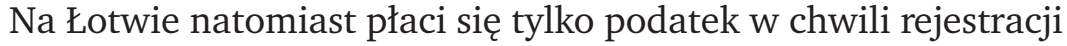
pojazdu. Wysokość tego podatku jest uzależniona tylko od poziomu emisji $\mathrm{CO}_{2}$.

\section{EUROPEJSKIE ROZWIAZZANIA WSPIERAJĄCE KUPNO NOWYCH SAMOCHODÓW}

Niektóre kraje europejskie oprócz obciążania właścicieli samochodów licznymi podatkami, wprowadzają pewne rozwiązania zachęcające do kupna nowych, bardziej ekologicznych aut. Na przykład na terenie Austrii właściciele pojazdów, które emitują ponad $150 \mathrm{~g} / \mathrm{km} \mathrm{CO}_{2}$ płacą 25 euro za każdy dodatkowy gram $^{36}$. Jednak jeżeli auto emituje poniżej $120 \mathrm{~g} / \mathrm{km} \mathrm{CO}_{2}$ wówczas właściciel auta dostaje „premię” w wysokości maksymalnej

35 Dla pojazdów emitujących ponad $225 \mathrm{~g} / \mathrm{km}$.

${ }^{36}$ W przypadku, gdy emisja CO2 przekracza $170 \mathrm{~g} / \mathrm{km}$ właściciel zobowiązany jest zapłacić kolejne 25 euro za każdy przekroczony gram. Szerzej: Bundesministerium für Finanzen, Österreich https://www.bmf.gv.at/steuern/ fahrzeuge/normverbrauchsabgabe.html\#heading_Bonus_Malus_f_r_CO2_ und_NOx_Emissionen_sowie_f_r_Partikelfilter 
do 300 euro. Dla pojazdów zasilanych paliwami alternatywnymi „premia” może wynieść nawet 500 euro.

Na terenie Luksemburga, wysokość podatku ekologicznego jest obliczana na podstawie emisji $\mathrm{CO}_{2}$ pomnożonej przez współczynnik rodzaju paliwa. Dla silnika diesla wynosi on 0,9 a dla innych paliw 0,6. Również i w tym przypadku właściciele silników diesla są wyżej opodatkowani niż właściciele aut napędzanych benzyną czy gazem LPG. W przypadku zakupu nowego auta charakteryzującego się emisją $\mathrm{CO}_{2}$ poniżej $60 \mathrm{~g} / \mathrm{km}$, kupujący otrzymuje „premię” w wysokości 5000 euro $^{37}$.

W Szwecji natomiast wysokość podatku ekologicznego uzależniona jest od poziomu normy czystości spalin oraz od wieku auta. Dodatkowo posiadacze aut napędzanych olejem napędowym płacą podatek pomnożony przez współczynnik wynoszący 2,33 w stosunku do innych rodzajów paliwa. Jednakże w przypadku zakupu auta kwalifikowanego przez ustawodawcę za pomocą równania matematycznego jako „zielone”, właściciel pojazdu jest zwolniony z tego podatku przez okres 5 lat.

\section{SAMOCHODY WSPOMAGANE LUB NAPĘDZANE ENERGIĄ ELEKTRYCZNĄ}

W przypadku aut wspomaganych lub napędzanych energią elektryczną można wyróżnić pojazdy hybrydowe ${ }^{38}$ i pojazdy elektryczne ${ }^{39}$. Wśród pojazdów hybrydowych można wyróżnić

37 Jednakże dodatkowym warunkiem otrzymania tej bonifikaty jest oświadczenie oraz przestrzeganie przez użytkownika pojazdu zakupu energii elektrycznej pochodzącej tylko z odnawialnych źródeł energii. Należy zauważyć, iż nie jest to z reguły prosty warunek do spełnienia.

38 Zgodnie z art. 3 pkt 1 rozporządzenia 715/2007, „pojazd hybrydowy” jest to pojazd wyposażony przynajmniej w dwa różne konwertery energii i dwa różne systemy przechowywania energii (w pojeździe) napędzające pojazd.

39 Zgodnie z Regulaminem nr 101 Europejskiej Komisji Gospodarczej Organizacji Narodów Zjednoczonych (EKG ONZ) - Jednolite przepisy dotyczące homologacji samochodów osobowych wyposażonych wyłącznie w silnik spa- 
tradycyjne auta hybrydowe czyli takie w których występuje zamknięty obwód energii elektrycznej oraz auta hybrydowe typu „plug-in”, które umożliwiają doładowanie energii elektrycznej ze źródła zewnętrznego czy np. z tradycyjnego gniazdka 230V. W przypadku aut tradycyjnie hybrydowych w chwili niskiego poziomu naładowania akumulatorów uruchamia się silnik spalinowy przeważnie do chwili pełnego naładowania akumulatorów. Natomiast auta hybrydowe typu „plug-in” można doładować energią elektryczną w specjalnych punktach doładowań czy w domowym garażu.

Auta elektryczne nie podlegają opodatkowaniu ekologicznemu od emisji spalin. Jednak z uwagi na wysoka cenę auta elektrycznego oraz wysokie koszty eksploatacyjne związane z wymogiem wypożyczania baterii od producenta, zwolnienie z podatku ekologicznego może nie być wystarczającym argumentem przemawiającym za kupnem takiego pojazdu. Zwłaszcza ze zakup auta elektrycznego wiąże się nadal z ograniczeniami osiągów takiego auta oraz brakiem pełnej swobody poruszania się gdyż trzeba swoją podróż zaplanować tak, aby była możliwość uzupełnienia akumulatorów ze źródła zewnętrznego. W ramach zachęty do kupna i użytkowania aut elektrycznych niektóre kraje całkowicie lub częściowo zwalniają posiadaczy aut elektrycznych z innych form opodatkowania ${ }^{40}$. I tak przykła-

linowy spalania wewnętrznego lub wyposażonych w hybrydowy elektryczny układ napędowy w zakresie pomiaru emisji dwutlenku węgla i zużycia paliwa i/lub pomiaru zużycia energii elektrycznej i zasięgu przy zasilaniu energią elektryczną oraz pojazdów kategorii $\mathrm{M}_{1}$ i $\mathrm{N}_{1}$ wyposażonych $\mathrm{w}$ elektryczny układ napędowy w zakresie pomiaru zużycia energii elektrycznej i zasięgu przy zasilaniu energią elektryczną (Dz.Urz. UE L 138 z dnia 26 maja 2012 r., s. 1), „pojazd elektryczny” oznacza pojazd wyposażony wyłącznie w elektryczny układ napędowy. Elektryczny układ napędowy, zgodnie z Regulaminem, oznacza system złożony z jednego lub więcej układów do magazynowania energii elektrycznej (np. akumulatora, elektromechanicznego koła zamachowego lub ultrakondensatora), jednego lub więcej kondycjonerów energii elektrycznej i jednego lub więcej urządzeń elektrycznych, które przekształcają zachowaną energię elektryczną w energię mechaniczną dostarczaną do kół w celu zapewnienia napędu pojazdu.

40 Analiza i omówienie rozwiązań zostało dokonane w oparciu o dane przedstawione przez ACEA - Europejskie Stowarzyszenie Producentów Pojazdów 
dowo Królestwo Danii zwalnia posiadaczy aut elektrycznych nie cięższych niż 2 tony od podatku rejestracyjnego.

Niektóre kraje ${ }^{41}$ traktują auta elektryczne i hybrydowe na równi - zwalniając ich posiadaczy z płacenia podatku drogowego czy rejestracyjnego. Większość krajów natomiast różnicuje auta hybrydowe od aut elektrycznych. W Austrii auta elektryczne są zwolnione $\mathrm{z}$ miesięcznego podatku od posiadanego pojazdu, natomiast auta hybrydowe są traktowane jako pojazdy zasilane alternatywnym źródłem zasilania zatem podlegają ogólnemu opodatkowaniu ekologicznemu. W Portugalii auta elektryczne są zwolnione z podatku rejestracyjnego oraz z rocznego podatku drogowego. Auta hybrydowe natomiast uzyskują 50\% zniżkę w przypadku podatku rejestracyjnego.

Niektóre kraje europejskie subsydiują dodatkowo auta elektryczne. I tak na terenie Zjednoczonego Królestwa Wielkiej Brytanii oprócz ulg podatkowych, nabywcy nowych aut elektrycznych oraz aut hybrydowych typu „plug-in” o emisji $\mathrm{CO}_{2}$ poniżej $75 \mathrm{~g} / \mathrm{km}$ mogą otrzymać dodatkowo premię w wysokości nawet $25 \%$ ceny auta, o ile nie przekroczą maksymalnej kwoty bonifikaty wynoszącej 8000 funtów szterlingów. We Francji właściciele pojazdów emitujących poniżej $20 \mathrm{~g} / \mathrm{km} \mathrm{CO}_{2}$, co w rzeczywistości dotyczy tylko aut elektrycznych, mogą otrzymać wsparcie do 7000 euro przy zakupie nowego auta. Natomiast, właściciele aut emitujących $20-50 \mathrm{~g} / \mathrm{km} \mathrm{CO}_{2}$ mogą otrzymać wsparcie do 5000 euro, a w przypadku $50-60 \mathrm{~g} / \mathrm{km} \mathrm{CO}_{2}$ do 4500 euro. Takie wsparcie jest skierowane głównie do potencjalnych posiadaczy aut hybrydowych typu „plug-in” lub najnowszych konstrukcji aut tradycyjnie hybrydowych.

Analizując aspekt emitowania szkodliwych związków poprzez korzystanie z samochodów przez osoby prywatne, należy również zwrócić uwagę na kwestię użytkowania aut przez firmy oraz „zachęt” skierowanych do tej grupy przez państwa w celu korzystania z bardziej ekologicznych rozwiązań. Należy pamię-

http://www.acea.be/uploads/publications/Electric_vehicles_overview_2013. pdf, data pobrania: 11 marzec 2014.

41 Jako przykład można w tym miejscu wskazać: Rumunię, Grecję czy Re1/2014 publikę Czeską. 
tać, iż firmy posiadają z reguły szeroką flotę pojazdów służbowych, z których często korzysta spora grupa pracowników. W przypadku aut służbowych oprócz aspektu kilometrowego, a tym samym mniejszej ilości zanieczyszczeń w przypadku aut wspomaganych lub napędzanych energią elektryczną, należy również zauważyć, iż w przypadku aut firmowych większa grupa osób ma możliwość przetestowania „ekologicznego samochodu". Zazwyczaj jedno auto w firmie przypada na sporą ilość osób. Jeżeli pojazd okaże się niezawodny i przyjazny w użytkowaniu wówczas część osób decyduje się na zakup i korzystanie $\mathrm{z}$ takiego pojazdu w celach prywatnych.

Część krajów wprowadziła pewne bonifikaty szczególnie ukierunkowane do podmiotów prawnych. We Francji auta elektryczne należące do firm są zwolnione dodatkowo z podatku samochodowego. Dla aut hybrydowych emitujących mniej niż $110 \mathrm{~g} / \mathrm{km} \mathrm{CO}_{2}$ zwolnienie to przysługuje przez pierwsze dwa lata od daty pierwszej rejestracji. W Wielkiej Brytanii natomiast elektryczne auta firmowe są zwolnione z podatku samochodowego do kwietnia 2015 roku. Wszelkie zwolnienia i zachęty skierowane do podmiotów prawnych to słuszne rozwiązanie służące rozpowszechnianiu użytkowania ekologicznych pojazdów.

\section{ZAKOŃCZENIE}

Przepisy unijne ustanawiają ograniczenia dotyczące średniego poziomu emisji $\mathrm{CO}_{2} \mathrm{z}$ nowych samochodów osobowych oraz regulują m.in. kwestię przekroczenia poziomów emisji. Ujednolicają również wymogi techniczne w zakresie homologacji pojazdów silnikowych pod kątem emisji zanieczyszczeń. Przepisy te nakładają na państwa członkowskie zobowiązania, które mają na celu redukcję emisji spalin.

Próby osiągnięcia redukcji emisji szkodliwych substancji podejmowane są za pomocą różnych środków. Temu celowi służy m.in. wprowadzenie stref niskiej emisji oraz opłat za wjazd do centrum miast. Ograniczenie wjazdu do centrów miast, sa- 
mochodów emitujących dużą ilość spalin ma działanie dwukierunkowe. $\mathrm{Z}$ jednej strony ogranicza emisję gazów w centrum miasta, a jednocześnie oddziałuje na właścicieli pojazdów wymuszając na nich zakup takich aut, które są ekologiczne i którymi można poruszać się w centrum aglomeracji. Również opodatkowanie samochodów od emisji spalin ma przede wszystkim oddziaływać na właścicieli samochodów. Co do zasady wyższe podatki płacą posiadacze starszych modeli aut z silnikiem wysokoprężnym, które emitują więcej $\mathrm{CO}_{2}$. Państwa członkowskie stosują również metody zachęcające, w postaci specjalnych dopłat, dla nabywców samochodów wspomaganych lub napędzanych energią elektryczną.

Podkreślić należy, iż wszelkie instrumenty stosowane przez państwa członkowskie mają jeden cel - zmniejszyć ilość emisji szkodliwych substancji.

Kontakt e-mail:

magdalenajas@gmail.com 